\title{
Influence of Photopolymerization Light Source on Enamel Shear Bond Strength after Bleaching
}

\author{
Sandro Cordeiro LORETTO ${ }^{1}$ \\ Rodivan BRAZ ${ }^{1}$ \\ Arine Maria Víveros de Castro LYRA ${ }^{1}$ \\ Luís Mário LOPES ${ }^{2}$ \\ ${ }^{1}$ Department of Restorative Dentistry, Faculty of Dentistry of Pernambuco, UPE, Camaragibe, PE, Brazil \\ ${ }^{2}$ Private Dental Practice, Recife, PE, Brazil
}

\begin{abstract}
This study evaluated the influence of 3 different photopolymerization sources on enamel shear bond strength after bleaching with $10 \%$ carbamide peroxide. Seventy-two incisive bovine teeth were randomly divided into 6 groups $(\mathrm{n}=12)$ according to bleaching treatment and photopolymerization source used: G1 - Bleached / Halogen lamp; G2 - Not bleached / Halogen lamp (control); G3 - Bleached / Light-emitting diodes (LED); G4 - Not bleached / Light-emitting diodes (LED) (control); G5 - Bleached / Xenon plasma arc; G6 - Not bleached / Xenon plasma arc (control). Experimental groups were exposed to bleaching agent for a period of 14 days, with a daily contact of $4 \mathrm{~h}$ and then stored in artificial saliva at $37^{\circ} \mathrm{C}$. Control groups were stored in artificial saliva at $37^{\circ} \mathrm{C}$ for same period of bleaching treatment. Procedures for bonding composite resin to enamel were carried out according to manufacturer instructions. After storage in distilled water at $37^{\circ} \mathrm{C}$ for 24 hours, all samples were submitted to shear bond strength test. G2 had the highest mean value $(14.86 \mathrm{MPa})$ while $\mathrm{G} 5$ had the lowest $(12.32 \mathrm{MPa})$. The comparison of groups by 2-way ANOVA showed that there were no significant differences for either of the factors considered in this study (bleaching and photopolymerization source), hence the interaction between these factors. It was therefore possible to conclude that neither enamel bleaching nor the photopolymerization source used had any influence on enamel shear bond strength.
\end{abstract}

Key Words: dental bleaching, dental enamel, bond strength.

\section{INTRODUCTION}

Dental bleaching has been used as a feasible alternative for discolored teeth. This treatment has been used in dentistry for many years, and its popularity has grown since the introduction of nightguard vital bleaching. However, the clinical application of this procedure preceded an understanding of all its implications, and a number of doubts remain concerning its use. Among these, the replacement of adhesive fillings immediately after nightguard vital bleaching lacks any scientific basis to guide the professionals as to the optimal conduct to adopt (1).

Previous research on this subject has shown no agreement either on the possible decrease in bond strength caused by dental bleaching or on the necessary waiting time for the replacement of adhesive fillings after these treatments (1). Nevertheless, a great number of scientific publications assert that residual oxygen from the bleaching agent, present in dental enamel, could be the cause of failure in adhesive procedures after bleaching. This mechanism is triggered by the inhibition of the adhesive system and composite resin polymerization, accounting for the postponement of restorative treatment after bleaching (2-6).

In addition, recent advances in knowledge and alternatives to photopolymerization of dental materials have come to the fore, exemplified by changes in the composition of the materials, especially composite resins, and in the kind of light sources used in this process. These changes are intended to ensure desirable mechanical properties and longevity of the final product, as well as to minimize failure originating in the photopolymerization process, such as the inappropriate con-

Correspondence: Prof. Sandro Cordeiro Loretto, Faculdade de Odontologia de Pernambuco, UPE, Setor de Pós-Graduação, Av. General Newton Cavalcanti 1650, 54753-220 Camaragibe, PE, Brasil. Tel/Fax: +55-81-3458-1208. e-mail: sandroloretto@hotmail.com 
version of monomers, exaggerated polymerization shrinkage, marginal leakage and postoperative pain (7).

In this context, the dental market has introduced photopolymerization devices based on new light sources, represented by LEDs (light-emitting diodes) and the xenon plasma arc, which are alternatives to conventional halogen lamp units. Scientific research is being undertaken to evaluate their laboratory and clinical feasibility. These new technologies have advantages, such as no heat generation during curing, lessened photopolymerization time, allowing overall procedures to be shorter and more integrated, and the fact that they last longer, eliminating the need for frequent replacement (8).

Thus, faced with the need to postpone the replacement of direct and indirect fillings after the nightguard vital bleaching treatment, for a period of up to 21 days (1), thereby increasing the patient's anxiety, it is important to evaluate the possibility that these recent photopolymerization sources may reduce, or even eliminate, the waiting time, through a polymerization process that ensures better physical and mechanical qualities for the final filling.

\section{MATERIAL AND METHODS}

Seventy-two sound incisive bovine teeth were used. Teeth were scaled with a periodontal scaler to remove organic debris before cleaning with water/ pumice slurry. After cleaning, the teeth were stored in distilled water and cooled to $4^{\circ} \mathrm{C}$ until the beginning of the test. Crowns were cut at the cementum-enamel junction using a diamond disc (KG Sorensen, Barueri, SP, Brazil), and each one was placed inside a PVC matrix $2.5 \mathrm{~cm}$ in diameter and $3 \mathrm{~cm}$ in height with buccal surfaces exposed to the external side of the border of the matrix. All matrixes were filled with selfcuring acrylic resin. Specimens were inserted into a round metallic mould and the buccal enamel surfaces polished with wet $600-, 1000$ - and 1200-grit aluminum oxide abrasive paper on a polishing machine (Panambra DP 10, Panambra Industrial e Técnica S.A., São Paulo, SP, Brazil).

Specimens were randomly divided into 6 groups $(\mathrm{n}=12)$, according to bleaching treatment and photopolymerization source used: G1 - bleached / halogen lamp; G2 - not bleached / halogen lamp (control); G3 - bleached / LED; G4 - not bleached / LED (control); G5 - bleached / xenon plasma arc; G6 - not bleached / xenon plasma arc (control).

A heat and vacuum tray-forming machine (BIOART P3, Bioart Equipamentos Odontológicos, São Carlos, SP, Brazil) was used to produce 36 individual trays from 0.02-inch soft plastic. A reservoir in each tray helped to keep the bleaching gel and artificial saliva (with an electrolyte composition similar to that of human saliva) in contact with teeth.

The experimental groups (G1, G3 and G5) were exposed to one daily application of $10 \%$ carbamide peroxide (Whiteness, FGM Produtos Odontológicos, Joinville, SC, Brazil) for $4 \mathrm{~h}$ during 14 consecutive days, according to manufacturer instructions. In each tray, approximately $0.1 \mathrm{ml}$ of bleaching agent and 0.05 $\mathrm{ml}$ of artificial saliva were applied, following which the enamel surfaces of the specimens were covered. During bleaching, specimens were kept at $100 \%$ relative humidity and $37^{\circ} \mathrm{C}$, and after daily bleaching, thoroughly rinsed in running water, using a soft bristle toothbrush for $10 \mathrm{~s}$, and stored in artificial saliva at $37^{\circ} \mathrm{C}$. The control groups (G2, G4 and G6) were kept in artificial saliva $\left(37^{\circ} \mathrm{C}\right)$, renewed daily, for the same period of bleaching treatment (14 days).

After the bleaching period, the experimental groups were stored in artificial saliva $\left(37^{\circ} \mathrm{C}\right)$ for $24 \mathrm{~h}$ followed by procedures of adhesive bonding. Immediately before bonding, all groups were thoroughly rinsed in running water, using a soft bristle toothbrush for 10 s. The same protocol was followed for the control groups.

Adhesive tape with a hole in the center $(3 \mathrm{~mm}$ in diameter) was fixed to the enamel surfaces, delimiting the area to be used to bond the composite resin. All specimens were etched with $37 \%$ phosphoric acid gel (Scotchbond, 3M ESPE Dental Products, St. Paul, MN, USA) for $30 \mathrm{~s}$. The Single Bond (3M ESPE) adhesive system was applied in 2 consecutive coats and photopolymerized according to the light sources used: halogen lamp (ULTRALUX, Dabi Atlante, Ribeirão Preto, SP, Brazil) - 10 s; LED (ULTRABLUE II, DMC Equipamentos, São Paulo, SP, Brazil) - 10 s; xenon plasma arc (APOLlO 95E ELITE, Dental/Medical Diagnostic Systems, Westlake Village, CA, USA) - $3 \mathrm{~s}$.

To build the restoration, a stainless steel round mould with a central hole $3 \mathrm{~mm}$ in diameter and $4 \mathrm{~mm}$ in height, longitudinally cut, was positioned over the 
specimens in such a way that the central hole coincided with the delimited area of enamel. Filtek Z250 (3M ESPE) composite resin was inserted in 2 increments, and each was photopolymerized according to the light sources used: halogen lamp - 20 s; LED - 20 s; xenon plasma arc $-3 \mathrm{~s}$.

After the composite cylinders had been prepared, the specimens were stored in distilled water $\left(37^{\circ}\right)$ for $24 \mathrm{~h}$, and were subsequently submitted to the shear bond strength test in a Kratos machine (Kratos Equipamentos Industriais LTDA, Taboão da Serra, SP, Brazil).

The comparison between groups was made by ANOVA. As two factors were to be analyzed (light source and bleaching treatment), the two-way method was chosen. The $\mathrm{F}$ test evaluated the interaction between groups through the inferential technique.

\section{RESULTS}

The results are shown in Table 1. No significant differences were found for either factor (light source: $p$ $=0.387$; bleaching: $p=0.434$ ) or for the interaction of these factors (light source $\mathrm{x}$ bleaching: $\mathrm{p}=0.132$ ).

\section{DISCUSSION}

The shear bond strength test, as performed in this in vitro study, was chosen for its proven efficiency in similar research (2-5,9-13), and also because it is easy to perform and may provide answers to the questions raised in this study.

The bleaching treatment in the experimental groups followed the laboratory method described by

Table 1. Statistics of shear bond strength related to light source used and bleaching treatment.

\begin{tabular}{|c|c|c|c|}
\hline Treatment & $\begin{array}{c}\text { Mean } \pm \text { SD } \\
(\mathrm{MPa})\end{array}$ & $\begin{array}{l}\text { Variation } \\
\text { Coefficient (\%) }\end{array}$ & $\begin{array}{c}{[\mathrm{MIN} ; \mathrm{MAX}]} \\
(\mathrm{MPa})\end{array}$ \\
\hline G1 Halogen Lamp/Bleached & $13.47 \pm 1.34$ & 9.98 & {$[11.65 ; 16.23]$} \\
\hline G2 Halogen Lamp/Not Bleached & $14.86 \pm 2.10$ & 14.15 & {$[11.93 ; 18.59]$} \\
\hline G3 LED/Bleached & $14.22 \pm 2.84$ & 19.97 & {$[10.12 ; 20.39]$} \\
\hline G4 LED/Not Bleached & $12.86 \pm 2.80$ & 21.74 & {$[8.18 ; 18.86]$} \\
\hline G5 Xenon Plasma Arc/Bleached & $12.32 \pm 2.74$ & 22.25 & {$[8.04 ; 16.23]$} \\
\hline G6 Xenon Plasma Arc/Not Bleached & $13.81 \pm 3.93$ & 28.45 & {$[8.87 ; 22.61]$} \\
\hline
\end{tabular}

Cavalli et al. (13). The procedures of preparing trays, inserting the bleaching agent and artificial saliva, daily exposure ( $4 \mathrm{~h}$ ) and bleaching period (14 days), rinsing in running water and brushing enamel surfaces using an appropriate toothbrush, besides storing specimens in artificial saliva, were done in such a way as to reproduce, as much as possible, clinical situations resulting from nightguard vital bleaching.

The $10 \%$ carbamide peroxide concentration is the one most frequently used in at-home bleaching treatments due to its proven effectiveness (14), because higher concentrations (16-22\%) are often related to post-treatment sensitivity.

Several studies have been conducted to evaluate the interaction between bleaching treatments and the bonding capacity of dental substrates. The results, although sometimes divergent possibly for methodological reasons, point to a decrease in the bond strength of dental tissues submitted to bleaching, meaning that the possible presence of residual oxygen could interfere with resin attachment and inhibit resin polymerization. The reversal of this process is dependent on the time elapsed since bleaching treatment (2-5,9-13).

A number of options were proposed to counter this drawback, such as roughening or removing superficial enamel after bleaching (15), or using adhesive systems with solvents, such as alcohol or acetone $(3,16)$, able to displace water from the enamel surface. However, the application of such alternative techniques is not reaffirmed in dental literature as a common clinical procedure that could guarantee success when bonding to bleached enamel.

Among the justifications for the results of the present study, the storage media of specimens may be highlighted. Artificial saliva was previously credited as being responsible for no differences in bond strength after bleaching procedures, according to the research of Murchison et al. (17) and Josey et al. (11). This may be attributed to the saliva remineralization effect, mentioned by Souza (18), which states that specimens treated with $10 \%$ carbamide peroxide and stored in artificial saliva presented smaller spaces between hydroxyapatite crystals. However, Swift Jr. 
and Perdigão (19) considered that the possible saliva remineralization effect is still controversial.

On the other hand, Soares et al. (6) and Cavalli et al. (13), who also used artificial saliva as storage media, found lower values of enamel and dentin bond strength after at-home bleaching treatment. It, thus, seems reasonable to share the doubts expressed about the saliva remineralization effect, pointing to the need for further research aimed at evaluating the effects of this storage medium.

Furthermore, the elapsed time following bleaching to perform bond adhesion may have influenced the present results. It is imperative to emphasize that, in this study, specimens were stored in artificial saliva for $24 \mathrm{~h}$ prior to the bonding procedures, and for a further $24 \mathrm{~h}$ in distilled water prior to the shear bond strength test, i.e. a total of $48 \mathrm{~h}$ between the end of bleaching and the mechanical test. Titley et al. (2) and Dishman et al. (4), who performed bonding procedures immediately after bleaching, reported a decrease in enamel bond strength, which is differs from the results observed in this study, where no significant differences after bleaching were seen.

Torneck et al. (10) demonstrated that storage time after bleaching influences bond strength results. These authors used distilled water, rather than artificial saliva, as storage medium and found a direct relation between storage time and recovery of the substrate's adhesive capacity.

Another possibility that may be considered to explain the lack of any significant differences between the experimental and control groups, as suggested by Homewood et al. (20), is brushing enamel surfaces after bleaching. This procedure may be responsible for the elimination of a surface-precipitate formed on the tooth surface after bleaching (9), or for the removal of a bleaching partially etched superficial enamel, which on scanning electron microscopy shows numerous narrow depressions and an increase in porosity (11).

The composition of the adhesive system used may also have an influence on results. According to Sung et al. (12), alcohol-based adhesive systems permit the recovery of enamel bonding capacity. This aspect had already been reported by Kalili et al. (16), who state that alcohol present in a bonding agent could interact with residual oxygen from bleaching found on the structure of enamel. This is in agreement with the results of the present study in which an alcohol- and water-based adhesive system was used, contributing to the absence of significant differences in bond strength between the experimental (bleached) and the control (not bleached) groups.

It is thus important to emphasize that the results observed in the present study are difficult to compare with those of other research, firstly because the laboratory methods used are extremely different and, secondly, because there are no studies that have jointly evaluated the photopolymerization light source factor and bleaching treatment.

Taking into account the above mentioned limitations, it is possible to conclude that bleaching dental enamel with $10 \%$ carbamide peroxide did not affect adhesive bonding procedures performed $24 \mathrm{~h}$ after bleaching treatment and that the kind of photopolymerization light source (halogen lamp, LED and xenon plasma arc) employed did not affect enamel bond strength after bleaching with $10 \%$ carbamide peroxide.

\section{RESUMO}

Este estudo avaliou a influência do tipo de fonte fotopolimerizadora na resistência ao cisalhamento da união adesiva ao esmalte clareado com peróxido de carbamida a $10 \%$. Setenta e dois dentes incisivos bovinos íntegros foram divididos em 6 grupos $(n=12)$ de acordo com a realização ou não do tratamento clareador e com a fonte fotoativadora empregada: G1 - clareamento/luz halógena; G2 - sem clareamento (controle)/luz halógena; G3 clareamento/LED; G4 - sem clareamento (controle)/LED; G5 clareamento/arco de plasma de xenônio; G6 - sem clareamento/ arco de plasma de xenônio. Os grupos experimentais foram submetidos ao clareamento por um período de 14 dias, com exposição diária 4 horas. Os grupos controle foram armazenados em saliva artificial, a $37^{\circ} \mathrm{C}$, por período igual ao clareamento. A união da resina composta ao esmalte obedeceu às recomendações dos fabricantes. Em seguida, todos os corpos de prova foram armazenados em água destilada, por 24 horas, a $37^{\circ} \mathrm{C}$, até a realização do ensaio de resistência ao cisalhamento. $\mathrm{O}$ maior valor médio de resistência $(14,86 \mathrm{MPa})$ foi obtido para o grupo G2, e o menor para o grupo G5 (12,32 MPa). A comparação dos grupos através da análise de variância (ANOVA 2-way) demonstrou não haver diferenças significativas para ambos os fatores considerados neste estudo (clareamento e tipo de fonte fotopolimerizadora), bem como para a interação entre estes. Sendo assim, foi possível concluir que o clareamento do esmalte bem como o tipo de fonte fotopolimerizadora utilizada, não interferiram na resistência da união adesiva a este substrato.

\section{ACKNOWLEDGMENTS}

The authors would like to thank Ricardo Souza Antunes, Edson Volta, Paulo César Simamoto Júnior, and Gustavo Mendonça for their contributions during the development of this work. 


\section{REFERENCES}

1. Campos I, Pimenta LAF. Substituição de restaurações após o clareamento dental caseiro. Rev ABO Nac 2000;8:273-277.

2. Titley KC, Torneck CD, Ruse ND, Krmec D. Adhesion of a resin composite to bleached and unbleached human enamel. J Endod 1993;19:112-115.

3. Barghi N, Godwin JM. Reducing the adverse effect of bleaching on composite-enamel bond. J Esthet Dent 1994;6:157-161.

4. Dishman MV, Covey DA, Baughan LW. The effects of peroxide bleaching on composite to enamel bond strengths. Dent Mater 1994;9:33-36.

5. Ben-Amar A, Liberman R, Gorfil C, Bernstein Y. Effect of mouthguard bleaching on enamel surface. Am J Dent 1995;8:2932 .

6. Soares CG, Pacheco JFM, Pires LAG. Resistência de união ao esmalte e dentina após clareamento com peróxido de carbamida. Rev ABO Nac 1998;6:210-213.

7. Althoff $\mathrm{O}$, Hartung M. Advances in light curing. Am J Dent 2000;13(special issue):77-81.

8. Christensen GJ. The curing light dilemma. J Am Dent Assoc 2002;133:761-763.

9. Titley KC, Torneck CD, Smith DC, Adibfar A. Adhesion of composite resin to bleached and unbleached bovine enamel. J Dent Res 1988;67:1523-1528.

10. Torneck CD, Titley KC, Smith DC, Adbifar A. Effect of water leaching on the adhesion of composite resin to bleached and unbleached bovine enamel. J Endod 1991;17:156-160.

11. Josey AL, Meyers IA, Romaniuk K, Symons AL. The effect of vital bleaching technique on enamel surface morphology and the bonding of composite resin to enamel. J Oral Rehab 1996;23:244250 .

12. Sung EC, Chan M, Mito R, Caputo AA. Effect of carbamide peroxide bleaching on the shear bond strength of composite to dental bonding agent enhanced enamel. J Prosthet Dent 1999;82:595-599.

13. Cavalli V, Reis AF, Giannini M, Ambrosano GM. The effect of elapsed time following bleaching on enamel bond strength of resin composite. Oper Dent 2001;26:597-602.

14. Haywood VB. Current status of nightguard vital bleaching. Compend Contin Educ Dent 2000;21(Supplement n.28):S10S17.

15. Cvitko E, Denehy GE, Swift EJ, Pires JF. Bond strength of composite resin to enamel bleached with carbamide peroxide. $\mathrm{J}$ Esthet Dent 1991;3:100-102.

16. Kalili T, Caputo AA, Mito R, Sperbeck G, Matyas J. In vitro toothbrush abrasion and bond strength of bleached enamel. Pract Periodontics Aesthet Dent 1991;3:22-24.

17. Murchison DR, Charlton DG, Moore BK. Carbamide peroxide bleaching: effects on enamel surface hardness and bonding. Oper Dent 1992;17:181-185.

18. Souza MAL. Clareamento caseiro de dentes: ação do peróxido de carbamida sobre dentes e mucosa bucal. [Doctoral Thesis]. Porto Alegre: Faculdade de Odontologia, Pontifícia Universidade Católica; 1993.

19. Swift Jr EJ, Perdigão J. Effects of bleaching on teeth and restorations. Compend Contin Educ Dent 1998;19:815-820.

20. Homewood C, Tyas M, Woods M. Bonding to previously bleached teeth. Aust Orthod J 2001;17:27-34.

Accepted March 15, 2004 